\title{
2. THE OPENNESS OF THE VISUAL ART CURRICULUM TOWARDS A NEW VISUAL ART LANGUAGE
}

Ana-Maria Aprotosoaie-Iftimi ${ }^{259}$

\begin{abstract}
Visual art curriculum should allow a wide range of activities to develop children's imagination and creativity, to provide a balanced framework for the harmonious development of people who can cope with the massive ammount of images that invade our daily lives. Contemporary art develops a new language - a hybrid language - which for now remains unknown to the majority of the public and it is not integrated into the Arts curriculum. General frame analysis reveals that Fine Arts are studied only up to the $10^{\text {th }}$ grade, except for the humanity profile and for the vocational arts profile. School curricula stipulate fine arts study up to mid twentieth century. Openness towards contemporary art and the language of art starting with the second half of the twentieth century is quite limited even if the curriculum allows a certain flexibility in the approach.
\end{abstract}

Key words: curriculum for visual arts, contemporary art, current syllabi, curriculum frameworks

\section{Introduction}

Arts subjects are integrated in the education of each individual from the earliest years of life. They are representative of two artistic fields, that is music and visual art, and they are part of the Arts curriculum. The curricular area represents a well-established range of school subjects which share some objectives and methodologies, and which offer a multi- and/or interdisciplinary vision on the study subjects. Arts curricular area includes disciplines such as Musical Education and Arts/Visual/Artistic Education. The framework plan is a way of solving the matter of study time distribution in which curricular areas are assigned, the compulsory subjects and the number of hours allocated weekly to each study subject.

\section{The Analysis of Curriculum Documents - Framework Plans and School Curricula}

A detailed analysis of the framework plans reveals that in the Romanian theoretical education, starting with the secondary level $\left(5^{\text {th }}-7^{\text {th }}\right.$ grades $)$ Arts are taught one hour a week in $5^{\text {th }}-7^{\text {th }}$ grades and a half hour a week in the $8^{\text {th }}$ grade. In high school, Arts are studied only up to the $10^{\text {th }}$ grade. Only in humanistic institutions, artistic disciplines are taught up to the $12^{\text {th }}$ grade. In what concerns vocational education, Plastic/Visual Arts are taught at secondary school and throughout the whole high school period. Compared to general-theoretic education, vocational education is found to manifest a significant increase in Arts specialty classes, differentiated according to profile and specialization. In schools with a technological profile or in vocational schools, the Arts curriculum is not covered by the framework plan.

\footnotetext{
259 Assistant Doctoral Candidate, "George Enescu" University of Arts from Iaşi of Romania, email: anamariaiftimi@gmail.com
} 
For each artistic discipline included in the learning framework plan, a curriculum is set, a part of the national curriculum. The curriculum describes the educational offer of a certain subject for a determined school course. Current school programs are developed in a unitary structure, keeping in consideration clearly defined curricular strategies, but the current national curriculum comes with a flexible learning offer. This allows teachers to adapt the formal framework - the curriculum requires the development of certain skills and completing certain contents - based on the personality and the specifics of the students they work with. The elements that facilitate this adjustment are represented by the fact that:

- the teacher can intervene in the succession of big content themes from the curriculum, but on condition that he maintains or ensures thematic coherence and he follows the internal logic of the field/discipline;

- in the curriculum - which is a centralized school document - there is no prescribed period of time allocated to each content item;

- examples of learning activities presented in the curriculum may be amended, supplemented or replaced.

These three aspects allow the development of a customized educational process, personalised depending on the specific development needs of the students and on the group they belong to. The instructive-educational contents: openness towards the new language of contemporary art. Analyzing the current curriculum, one can see a certain degree of openness towards artistic phenomena manifested since the second half of the twentieth century.

From a simple reading of the presentation note of the curriculum for $5^{\text {th }}$ $8^{\text {th }}$ grades, an orientation mainly towards fine arts training can be noticed, until the first part of the twentieth century. Content proponents, which are binding and which will be taught throughout the whole cycle, are artists and theorists strongly connected to the artistic movements of the $19^{\text {th }}$ century century and the first part of the $20^{\text {th }}$ century, including artistic movements and educational principles of the Bauhaus school. Therefore theories about shape, color, contrast and chromatic dominants, composition are systematized and structured in this direction. The conclusion is supported by the general skills, values and attitudes proposed to be developed by the secondary school curriculum, and by specific skills and mandatory contents specified for each level of study. However, changes made in 2009 to the curriculum for 5th - 8th grade through the revisions made compared to the previous curriculum reveal the possibility of introducing notions - even at a preliminary level - about understanding contemporary art manifestations strarting with the second half of the twentieth century.

National curriculum in Arts for 9th to 12th grades stipulates the use and also the development of the skills acquired by students in previous years. Learning the contents can provide the skills necessary for decoding any image, including images that contain aspects of daily life. The art of the twentieth century and that of the beginning of the twentyfirst century encompasses in its forms of expression the daily, ordinary, trivial character of life. Therefore, by 
learning the contents of the 9th - 12th grades curriculum, students will be able to contact directly, but also mediated by the teacher, the art of the present time. For example, it stipulates the capacity to identify some materials and techniques, their expressive function and the relationship between their two- and threedimensional image and the environment, by reviewing the information about materials and techniques; outdoor and indoor sculpture; architecture integrated into the natural urban environment or in artificial landscapes.

If the curriculum for middle school there are time conditionings through specifications on studying certain periods of art history in certain years of study, but also content conditionings suggesting studying modern artistic language in the first years of high school curriculum, these conditionings no longer exist or they are not longer so bidding. Skills and contents are designed and formulated in such a way that they allow for a greater flexibility in their approach based on the teacher's specialized training and his openness to artistic phenomena of the present time - postmodern times.

Regarding the 10th grade, the freedom of addressing information about artistic events that have occurred since the second half of the twentieth century and the beginning of the twentyfirst century is much greater than that of the 9th grade. The curriculum calls for highlighting the utility, communication or aesthetic functions of decorative arts through the study of the current environment, fire arts, instalations, performance, kinetic arts. It is stipulated the development of skills that should build the analysis capacity: the representation manner of time and space in kinetic arts, performing arts, TV, computer produced art, the expressive function of some materials and techniques used in art such as the set and the costumes in everyday life and in the performing arts.

It was thought to create skills designed to identify the meanings associated with the artistic message from the perceived visual universe and argumenting one's opinion regarding the subjective meanings by analyzing published critical opinions on various artistic events. This way, pictures, movies, TV shows can be discussed in class in order to identify the specific means of expression in various branches of art and their relationship with the environment; freely chosen materials and techniques can be used, either conventional and unconventional; computer graphics is encouraged. The images chosen as an example to illustrate the curriculum contents can be chosen from any historical period, thus present time art is included.

In 11th and 12th grade the immersion into contemporary art is even greater. Specific means of expression of various arts are studied, such as theater, dance, music, cinema, multimedia, photography, architecture, literature etc. Manners of communication through art are analyzed: indirect communication the triad of the artistic fact, namely the masterpiece - interpreter (intermediary) public (audiences); direct communication between the artwork and the public. Criteria are identified - aesthetic, ethical, educational, practical - for critical introspection in the consumer and producer stances of the artistic act. In contemporary art, the role of the art public has changed compared to the assigned role in previous centuries, that of receiver of the artistic message. In 
present times, in addition to being the receiver, the public is also a direct participant, co-creator of the artistic act. Therefore, starting with 9th grade, public's attitude is investigated through its reactions, as a landmark with possible positive or negative meanings - constructive - in relation to the artistic act; criteria assigned the role of informed consumer or producer of the artistic role are identified.

Regarding vocational education, from the analysis of competences and contents specific for the speciality disciplines, it is found that there is openness towards the artistic phenomena of the present time by studying the discipline Visual Education in 9th and 10th grades simultaneously with the study of specialized artistic disciplines. Instead, in the case of speciality subjects, one can see the thoroughgoing study of modern plastic language, a study that started during the years of middle school. Emphasis falls on the development of skills and on the formation of values such as: motivation for language learning and the use of terms specific for artistic language; expressing interest for transposing elements from the real, objective space into the plastic space by creating works of fine art, decorative and ambient art; plastic expression, using materials, tools and techniques specific for fine arts; expressing interest for systematic throughgoing study of various forms of expression of fine arts, etc. The contents directly support skills training for fine arts by acquiring a mostly modern specialized language.

The subject Art and Architecture History, which is also studied in high school, during the first years, includes skills and contents that could allow a flexible approach on artistic phenomena specific to the twentieth century and the early twenty-first century: architecture in the twentieth century, artistic currents and movements of the twentieth century - including abstract art - future trends and developments. General skills involve training value judgment and critical judgment in assessing an artistic work, and also linking information specific for different fields of knowledge using historical, literary, psychological, social and logic data. Besides the aesthetic and educational function of art, the development and the emphasizing of the cognitive function is also envisaged. This will help develop the ability to select and prioritize values by removing Kitsch type manifestations arising from industrialization and art commercialization. However, a mention of the syllabus limits the opportunity of the teaching staff to address nowadays artistic phenomena, and thus they must limit themselves to examining art creations in Western Europe, starting with the antiquity and ending with the mid twentieth century".

Starting with upper high school education, in vocational education, specialist training deepens through specific practices of Specialized Atelier and thorough a throughout study of art history in the specialist field - Plastic Arts History / Decorative Arts History / Architecture History / Ambient Art History / Design History. A discipline that is not part of the Arts curriculum and that belongs to the Technologies curricular area is Computerized Image Processing. This discipline is studied in high school, in the upper cycle, vocational branch, artistic profile, regardless of the specialization. The skills created within this 
discipline involve the ability to operate artistic image processing through computer technology so that one could be able to make graphic processing operations, operations with layers (layers) and multilayer images, working with filters and special effects, adding animated objects, color change, adding dominant traits, saturation, transparency. This will accustom the student with techniques such as: object rearrangement and resizing - moving, rotating, scaling, deformation; processing the image with the purpose of inserting them in various materials; manners of making boards, posters, advertising materials. This will form the necessary skills in order to operate with notions of royalty and copyright, concepts commonly used and widely debated in contemporary art and social practice.

All skills formed through the Digital image processing subject refer directly to the need to understand, assimilate and express in the contemporary artistic language, the present time art being a visual art mediated by technology. Therefore Digital image processing is one of the few disciplines that makes a clear transition to a representative part of nowadays art specific techniques.

\section{Curriculum Limits}

Present time art forces the audience to leave the position of mere viewer and to enter into a state of relfection on the message sent by it. Present time art is now inclined to challenge the receiver's intellect, rather than to satisfy the spirit. A stylistic plurality can be noticed; furthermore, art areas considered consecrated, such as music, visual arts, theater, choreography are no longer assigned to their frames (the ones that the public was used to), but they interfere with eachother, thay lend and borrow expression means, they reinvent them, or they invent new ones, leading to a syncretic art. Contemporary artists offer paintings that "sing", sculptures that "dance", they meet the need for color, shape, texture through sound and movement, just as they express sound or choreographic ideas through line, shape or color.

There are several aspects to the national curriculum which can restrict or impede creating the skills of receiving the artistic message and of expressing creative potencies, by reference to the present time art. Arts curriculum stipulates only two subjects related to arts, namely Music and Visual Arts, respectively Music Education and Arts/Visual/Fine Arts education. There are no general subjects covering art areas such as Theater and Choreography. Only in vocational schools there are specializations such as Choreography and Actor Arts, where, within specific artistic subjects, specialized skills are created for the youth with special skills in the field. Otherwise, in theoretical education, there are not even optional subjects open in this direction. Artistic educational activities are conducted in some schools, but they are theater and dance activities, as side activities during school festivals or school literary circles, taken over by literature or sports teachers, usually during secondary school. Of course this type of artistic activities - theater and dance- are designed from the perspective of the areas where those teachers work, and not from the perspective of a specialist in the field of theater and coreography. However, if we are to analyze these actions through the the perspective of interdisciplinarity, their aim 
is noble, but in terms of training the future audience of contemporary art, the theater and choreography or dance activities from schools should be coordinated by teachers trained in those fields and opened towards the contemporary artistic phenomenon.

The analysis goes beyond, noticing that in high school Arts subjects from the Arts curriculum are studied under the common core, that is Fine/Visual/Artistic Arts and Musical Education - only in junior high, regardless of the branch, in all specialties. Starting with the upper secondary level, only in theoretical humanities - Letters and Social Sciences - Arts Education is studied, without including Musical Education; young people who opt for the Science profile - Mathematics, Informatics - being deprived of skill training in the field of Visual Arts or Music. In the vocational branch, Pedagogical and Theological profile, the two artistic disciplines are still studied, differently, according to the specific profile, and in the Sports profile, only Musical Education is studied.

Concerning Vocational education, artistic profile, things are different. Thus, in junior high school, regardless of the artistic specilization, students are studying Fine Arts/Visual/Artistic and Musical Education, as part of the core curriculum. In senior highschool, however, in Music and Choreography specializations, Visual/Artistic Education is no longer taught; in specializations related to visual arts - Fine Art, Decorative Art, Architecture, Ambient Arts and Design - Music Education is no longer taught; and in the Choreography specialization, only Music Education is taught, without Visual Arts. Another aspect resulting from the curricular analysis regarding the regulation of the study of artistic disciplines is related to the absence of curricular documents.

It was found that there are no curricula for the Artistic Education subject for 12th grade, theoretical education, and also for the specialized artistic subjects in Arts vocational education, for the primary school (preparatory, 1st4th grades), middle school (5th- 8th grades) and senior highschool (11th-12th grades). No rules were found in this direction or large frames of reference to guide the teacher in teaching at these levels. Field studies show that for the artistic disciplines included in the situation revealed above, teachers either work according to their intuition, given their previous artistic experience, or they are guided by old school programs, dating since the beginning of the educational reform.

\section{Conclusions}

Generally, following the mandatory provisions but also the suggestions of the current curricula, the Romanian artistic educational act has the potential to develop young people capable of being active participants in cultural life, of receiving in a personal manner the artistic message and to formulate their own critical acclaim on the artistic phenomenon, to appreciate and to respect their own aesthetic sensitivity, but also that of others, in an intercultural context.

Current national curriculum aims to facilitate the development of psychic functions - emotion, feeling, thinking - that underlie the formation of the artistic communication skills and capacities, communication that is much more complex than the scientific one, that determines the harmonious development of the 
human being. Currently century art combines the two types of communication, and therefore both of them should be developed in a balanced manner in order to fight clutural stereotypes and uniformization. Furthermore, by correctly mastering the two types of communication, the foundations for training future art public are set, a public that can actively contribute to setting up the environment and to improving life ambiance. Therefore, the future art public won't be a simple passive receiver, easy to manipulate, but, through a harmonious development of the soul functions and of the intellectual abilities, it will be able to develop its own creative, response and selection capacities for the messages coming from the social environment, messages that can distort the perception of reality and of internal representations.

These aspects allow a flexible approach on the curriculum, based on possible factors such as: the openness of the teacher to the artistic phenomena that have been occurring since the second half of the twentieth century up to the present day, and how they are positioned through their own creation as against nowadays art; the perception of teachers involved in the artistic educational act on the theme of opening the current curriculum to contemporary art; the level of didactic experience of the teacher; the existence of support materials on contemporary art, etc.

\section{References $^{1}$}

${ }^{1}$ It is mentioned that the bibliography includes, except for the first two titles, curriculum documents governing the deployment of Romanian Arts education.

1. Ardelean, A., Mândruț, O. (coord.) (2012). Didactica formării competențelor. Cercetare - Dezvoltare - Inovare - Formare, Arad: Vasile Goldiș University Press

2. Negreț - Dobridor, I. (coord.) (2012). Programul de formare. Proiectarea curriculumului centrat pe competențe. Acreditat prin O.M.E.C.T.S. Nr. 4306/01/106/2012 - Suport de curs, Departamentul pentru Pregătirea personalului Didactic, Editor Inspectoratul Scolar Județean Teleorman

3. M.E.C.T., C.N.C. (2004). Programă școlară pentru clasa a IX-a, clasa a Xa, Ciclul inferior al liceului. Educație plastică, București: Ministerul Educaţiei, Cercetării și Tineretului, Consiliul Național pentru Curriculum

4. M.E.C., C.N.C. (2004). Programe școlare pentru clasa a IX-a, Ciclul inferior al liceului. Desen proiectiv, Elemente de perpectivă, Studiul compoziției, Studiul formelor și al culorii, Studiul formelor și al volumului, Studiul formelor şi al desenului, Istoria artelor şi arhitecturii, [Curriculum diferențiat]. Filiera vocaţională, profil artistic. Specializările: Arhitectură, Arte ambientale, Design, București: Ministerul Educației, Cercetării, Consiliul Naţional pentru Curriculum

5. M.E.C., C.N.C. (2005). Programe școlare pentru clasa a X-a. Ciclul inferior al liceului. Istoria artelor și arhitecturii, [Curriculum diferențiat], București: Ministerul Educației, Cercetării, Consiliul Național pentru Curriculum 6. M.E.C., C.N.C. (2006). Programe școlare pentru clasa a X-a. Ciclul inferior al liceului. Studiul compoziției, Studiul formelor și al culorii, Studiul formelor și 
al desenului, Crochiuri. [Curriculum diferențiat]. Filiera vocaţională, profil artistic. Specializările: Arte plastice, Arte decorative, Arhitectură, Arte ambientale, Design, București: Ministerul Educației, Cercetării, Consiliul Naţional pentru Curriculum

7. M.E.C., C.N.C. (2006). Programe școlare pentru clasa a XI-a. Ciclul superior al liceului. Educație artistică, Filiera teoretică, profil umanist, Filiera vocațională, profil teologic, București: Ministerul Educației, Cercetării, Consiliul Naţional pentru Curriculum

8. M.E.C.I. (2009). Programe şcolare. Educație plastică clasele a V-a, a VI-a, a VII-a, a VIII- $a$, București: Ministerul Educației, Cercetării și Inovării

9. M.E.C.I. (2009). Programe școlare. Procesarea computerizată a imaginii. Clasa a XI-a. Ciclul superior al liceului. Filiera vocaţională, profil artistic, specializările arhitectură, arte ambientale, design, arte plastice, arte decorative, București: Ministerul Educației, Cercetării și Inovării

10. M.E.C. (2001). ORDIN nr. 3638/11.04.2001 cu privire la aplicarea Planului-cadru de invăţământ pentru clasele I - a VIII-a în anul şcolar 20012002, București: Ministerul Educației și Cercetării

11. M.E.N. (2013). ORDIN nr. 3.371 din 12 martie 2013 privind aprobarea planurilor-cadru de invatamant pentru invatamantul primar si a Metodologiei privind aplicarea planurilor-cadru deinvatamant pentru invatamantul primar, București: Ministerul Educației Naționale

12. M.E.C.I. (2009). Ordin $n r$. 3410, din 16/03.2009 cu privire la aprobarea planurilor-cadru de învăţământ pentru clasele a IX-a - a XII-a, filierele teoretică şi vocaţională cursuri de zi, Anexal, Anexa 2, București: Ministerul Educației Cercetării și Inovării

13. M.E.C.I. (2009). Ordin $n r .3608$ din 13/04/200 9cu privire la aprobarea disciplinelor de specializare din curriculumul diferenţiat pentru clasele a IX-aa XII-a, ciclurile inferior şi superior ale liceului, filiera vocaţională; Anexa 1, Anexa 2, București: Ministerul Educației Cercetării și Inovării

14. http://programe.ise.ro/

15. http://edu.ro/ 